\title{
THE
}

\section{The Ocean as a Unique Therapeutic Environment: Developing a Surfing Program}

\author{
Emily D. Clapham \\ University of Rhode Island, eclapham@uri.edu \\ Cortney N. Armitano \\ University of Rhode Island \\ Linda S. Lamont \\ University of Rhode Island, lamont@uri.edu \\ Jennifer G. Audette \\ University of Rhode Island, jaudette@ri.edu
}

Follow this and additional works at: https://digitalcommons.uri.edu/kinesiology_facpubs
The University of Rhode Island Faculty have made this article openly available. Please let us know how Open Access to this research benefits you.

This is a pre-publication author manuscript of the final, published article.

Terms of Use

This article is made available under the terms and conditions applicable towards Open Access Policy Articles, as set forth in our Terms of Use.

\section{Citation/Publisher Attribution}

Emily D. Clapham, Cortney N. Armitano, Linda S. Lamont \& Jennifer G. Audette (2014) The Ocean as a Unique Therapeutic Environment: Developing a Surfing Program, Journal of Physical Education, Recreation \& Dance, 85:4, 8-14, DOI: 10.1080/07303084.2014.884424

Available at: http://dx.doi.org/10.1080/07303084.2014.884424 


\section{Abstract}

The lack of fitness and recreation opportunities for children with disabilities is problematic and can be consequential to proper health and development. All children need to accumulate 60 minutes or more of moderate-vigorous intensity activity throughout the day (World Health Organization, 2012). Adapted aquatics offers necessary physical activity and educational programming to children with disabilities and the benefits for children with disabilities are more pronounced and significant than for their able-bodied peers (Koury, 1996). Similar benefits could potentially be derived from surfing in the ocean. A twice weekly, eight-week surf instruction program was implemented for children with disabilities at a public beach in Rhode Island. The adapted surfing program was designed to develop and enhance the children's strength, flexibility, range of motion, coordination, balance, and psychosocial development. Children were recruited from local adapted physical education classes, the Rhode Island Special Olympics, and through flyers and word-of-mouth advertising. There were 17 participants and they ranged in age from 5 to 17 years. Our instructional goals were to teach the children to: 1) paddle while on the surfboard, 2) balance on the surfboards with their stomachs and in the seated, kneeling and standing positions, 3) learn to catch a wave and ride it into shore on their stomach and to progress to riding while sitting, kneeling and standing, and 4) paddling back out through the waves to repeat the process. Throughout the program, the children and surf instructors were encouraged to set realistic individual goals. There were many positive outcomes of the project including gains in social development and self-confidence.

Keywords: surfing program, children with disabilities 


\section{Background}

According to the World Health Organization (2010), children with disabilities have the same activity requirements as children without disabilities. The lack of fitness and recreation opportunities for children with disabilities is problematic and can be consequential to proper health and development. All children need to accumulate 60 minutes or more of moderatevigorous intensity activity throughout the day (World Health Organization, 2012). The participation of children with disabilities in sports and recreational activities promotes inclusion, minimizes deconditioning, optimizes physical functioning, and enhances overall well-being (Murphy, Carbone, and the Council on Children With Disabilities, 2008). Despite these benefits, children with disabilities are more restricted in their participation, have lower levels of fitness, and have higher levels of obesity than their able-bodied peers. (Murphy, Carbone, and the

Council on Children With Disabilities, 2008; Okagaki, Diamond, Kontos, \& Hestenes, 1998).

Children with learning disabilities are often alienated or excluded by typically developing children for both social and physical reasons.

Developmental disabilities affects about $13 \%$ of all children, and an average of 1 in 110 children in America have an Autism Spectrum Disorder (ASD) (CDC, 2011). Individuals with developmental disorders tend to have lower fitness and activity levels and, therefore, have decreased cardiorespiratory endurance, muscle strength, balance, coordination, and motor skills (Fragala-Pinkham M., Haley S.M., O’Neil, M.E., 2008). Children with autism demonstrate a higher rate of obesity and motor deficits than their able bodied peers (CDC, 2011). Furthermore, children with autism demonstrate hypotonia and motor apraxia (Ming, X., Brimacombe, M.,

44 Wagner, G.C., 2007). As with children with autism, children with Down's Syndrome have 
programs, including aquatic and land-based aerobics, have been proposed and studied for their ability to increase the fitness level of children with developmental disabilities.

Adapted aquatics offers necessary physical activity and educational programming to children with disabilities and the benefits for these students are more pronounced and significant than for their able-bodied peers (Koury, 1996). Due to water's buoyancy many children with disabilities, that would typically show an impaired mobility on land, are able to function independently in an aquatic environment. Often this can be done without the assistance of mobility devices such as braces, crutches, or walkers. It should be emphasized that swimming strengthens the muscles that allow for postural stability during both locomotor and object-control activities. Water supports the body, enabling some to walk for the first time, which can increase strength in those muscle groups needed for ambulating on land. Adapted aquatics also enhances breath control, upper body strength, flexibility and cardiorespiratory fitness (Yilmaz, I., Yanardag, M., Birkan, B., Bumin, G., 2004 \& Koury, 1996).

However, the benefits of aquatics are not limited to the physical domain. Carefully planned water activities that are implemented to meet a child's individual needs can contribute to psychosocial and cognitive development. Research with children with autism has demonstrated, a decrease in stereotypical movements: such as spinning, swinging and delayed echolalia (Yilmaz, I., Yanardag, M., Birkan, B., Bumin, G., 2004). Importantly, as a child with a physical disability learns to move through the water unassisted their self-esteem and self-awareness improve. This freedom of movement boosts morale and provides an incentive to maximize potential in other aspects of their rehabilitation (Koury, 1996). The motivational and therapeutic properties of water provide a stimulating learning environment for a child with a disability. 
Similar benefits could potentially be derived from surfing in the ocean. There are several

69

70

71

72

73

74

75

76

77

78

79

80

81

82

83

84

85

86

87

88

89

90 surf programs offered to people with disabilities around the world e.g. Surfers Healing, Ride-aWave, and the Disabled Surfer's Association in Australia. Surf programs for children with disabilities are quickly gaining popularity. Children with autism and other disabilities often become overwhelmed by sensory stimuli, suffer from severe social isolation, and lack communication skills (Delaney \& Madigan, 2009). The sport of surfing, like running, is solitary, repetitive, and requires determination and stamina; most children with autism possess these traits (Delaney \& Madigan, 2009). Furthermore, surfing provides the opportunity for independent participation without complicated rules or close contact with others potentially helping children with disabilities overcome social barriers (Delaney \& Madigan, 2009). Due to the properties of the ocean and the nature of the sport of surfing, another new and therapeutically beneficial option could be created for children with disabilities.

\section{Description of the Adapted Surf Program}

A twice weekly, eight-week surf instruction program was implemented for children with disabilities at a public beach in Rhode Island. The surfing program was designed to develop and enhance the children's strength, flexibility, range of motion, coordination, balance, and psychosocial development. The Brockport Physical Fitness Test (Winnick \& Short, 1999), heart rate monitors and activity monitors were used to measure physical changes before, during and after the implementation of the surf program. Children were recruited from local adapted physical education classes, the Rhode Island Special Olympics, and through flyers and word-ofmouth advertising. There were 17 participants and they ranged in age from 5 to 17 years. The university's Institutional Review Board (IRB) granted approval for the research and program, this ensured the safety and protection of the participants. Parents and guardians were required to 
91 sign forms of consent from the program leaders outlining the risks of participating in the surf

92 program. Participants were required to sign a form of assent from the program leaders also

93 outlining the risks of participating in the surf program. Prior to starting the program, all parents

94 and guardians were questioned regarding their child's swim ability and comfort levels in the

ocean. Children that were not viewed as good swimmers or comfortable in the ocean were not

recommended for participation in the surf program. Prior to the start of the program, a parent or guardian to the program leaders reported disability information for each child. Based on this information, the program leaders recruited trained volunteers to work one-on-one with each enrolled child. The volunteers were undergraduate and graduate students in Kinesiology and Physical Therapy as well as other members of the local university and surfing community. The program leaders in the departments of Kinesiology and Physical Therapy advertised the adapted surf program to students enrolled in their courses and requested assistance from their students. Students were also offered independent study credits and adapted physical education practicum hours for volunteering. Several volunteers were recruited from the local surf community. These volunteers willingly donated their time without compensation. All volunteers were welcomed and accepted by the program leaders.

The program leaders formally trained the volunteers. The program goals and skills were reviewed with the volunteers. Cue words and progressions of the skills were also presented to the volunteers. In addition, disability information about each child was privately shared with the child's volunteer instructor. The volunteer instructors were encouraged to find each child's 111 optimal learning style and offer an appropriate level of support that promoted full participation in 112 ocean surfing. Some children needed to participate in surfing hand-over-hand with their 113 instructor while others participated nearly independently. The level of support was determined 
114 by recommendations by parents and caregivers and observations by program leaders and 115 volunteer instructors. The volunteers were also encouraged to use aids like communication 116 boards, pictures and sign language to communicate with their assigned child. There was a formal 117 safety orientation by an experienced surfer from the local surfing community. She highlighted 118 safety precautions like how to prevent getting hit with the surfboard, rip tides in the ocean and 119 keeping children and instructors together at all times while in the ocean.

The local community was supportive of this program and provided beach access and 3 121 lifeguards were hired to patrol the beach for additional water safety. Surf equipment was rented 122 from a local surf shop and various sized surfboards were delivered to the beach each day. 123 Because of the varied sizes of the participants and program volunteers, and the need to wash 124 each wet suit after class, the suits were loaned to each for the entirety of the program. The 125 volunteers assisted the children with putting their wetsuits on. This is depicted in figure 1.

\section{Instructional Goals of the Adapted Surf Program:}

Instructional goals of the adapted surf program were to teach the children to: 1) paddle

128 while on the surfboard, 2) balance on the surfboards with their stomachs and in the seated,

129 kneeling and standing positions, 3) learn to catch a wave and ride it into shore on their stomach 130 and to progress to riding while sitting, kneeling and standing, and 4) paddling back out through 131 the waves to repeat the process.

First, the goals were reviewed and demonstrated using a large group instruction method. 133 Then, with their assigned volunteer instructor, all of the children practiced paddling, balancing 134 and moving into a sitting, kneeling and standing position on their surfboards while on the beach 
(before attempting to go into the ocean). The following is a description of how each skill was

explained:

\begin{tabular}{|c|c|c|}
\hline Surf Skill: & Cues from the instructor: & Modifications \\
\hline $\begin{array}{l}\text { Paddling } \\
\text { (Please see figure } 2 \text { for a } \\
\text { photograph of the skill.) }\end{array}$ & $\begin{array}{l}\text { 1. Lay prone in the center of } \\
\text { the surfboard. } \\
\text { 2. Balance in a comfortable } \\
\text { position prone in the } \\
\text { center of the surfboard. } \\
\text { 3. Alternate reaching and } \\
\text { pulling the sand or water } \\
\text { with your right and left } \\
\text { arm using an overhead } \\
\text { motion. }\end{array}$ & $\begin{array}{l}\text { 1. The child and } \\
\text { instructor can } \\
\text { paddle together on } \\
\text { the board in an "I" } \\
\text { formation. } \\
\text { 2. The instructor can } \\
\text { hold the child on } \\
\text { the board while } \\
\text { the child paddles. } \\
\text { 3. The child can use } \\
\text { a boogie board } \\
\text { instead of a } \\
\text { surfboard. } \\
\text { 4he child can use } \\
\text { a paddleboard } \\
\text { instead of a } \\
\text { surfboard. }\end{array}$ \\
\hline $\begin{array}{l}\text { Balancing } \\
\text { (Please see figures } 3 \text { and } 4 \text { for } \\
\text { photographs of this skill.) }\end{array}$ & $\begin{array}{l}\text { 1. Center yourself on your } \\
\text { board in a sitting or lying } \\
\text { position. } \\
\text { 2. Move your legs in a } \\
\text { circular motion. This will } \\
\text { give you more stability } \\
\text { on the surfboard. } \\
\text { 3. Once you are comfortable } \\
\text { in a seated position you } \\
\text { can try a lying position. } \\
\text { Let me know when you } \\
\text { are ready. } \\
\text { 4. Lie down in the center of } \\
\text { your board in a prone } \\
\text { position. }\end{array}$ & $\begin{array}{l}\text { 1. The child and } \\
\text { instructor can } \\
\text { balance together } \\
\text { on the board. } \\
\text { 2. The instructor can } \\
\text { hold the child on } \\
\text { the board while } \\
\text { the child attempts } \\
\text { to balance } \\
\text { independently. }\end{array}$ \\
\hline $\begin{array}{l}\text { Moving into a sitting position- } \\
\text { This was attempted once the } \\
\text { child progressed to successfully } \\
\text { catching waves in the prone } \\
\text { position with their surfboard. } \\
\text { (Please see figures } 5 \text { and } 6 \text { for } \\
\text { photographs of this skill.) }\end{array}$ & $\begin{array}{l}\text { 1. Once you catch a wave } \\
\text { with your surfboard, try } \\
\text { moving from lying on the } \\
\text { board to sitting on the } \\
\text { board. }\end{array}$ & $\begin{array}{l}\text { 1. The child and } \\
\text { instructor can start } \\
\text { and ride the waves } \\
\text { in together in the } \\
\text { seated position. } \\
\text { 2. The instructor can } \\
\text { push the child into }\end{array}$ \\
\hline
\end{tabular}




\begin{tabular}{|c|c|c|c|}
\hline & & & $\begin{array}{l}\text { the waves to help } \\
\text { the child catch the } \\
\text { wave with the } \\
\text { surfboard. } \\
\text { The child can } \\
\text { bodysurf the } \\
\text { waves without a } \\
\text { surfboard or use a } \\
\text { boogie board. }\end{array}$ \\
\hline $\begin{array}{l}\text { Moving into a kneeling } \\
\text { position- This was attempted } \\
\text { once the child progressed to } \\
\text { successfully catching waves in } \\
\text { the prone position with their } \\
\text { surfboard. } \\
\text { (Please see figure } 7 \text { for a } \\
\text { photograph of the skill.) }\end{array}$ & $\begin{array}{l}\text { 1. Once you catch a wave } \\
\text { with your surfboard, } \\
\text { kneel on the board after } \\
\text { catching a wave in the } \\
\text { lying position. }\end{array}$ & 3. & $\begin{array}{l}\text { The child can } \\
\text { catch and ride the } \\
\text { wave tandem in } \\
\text { the kneeling } \\
\text { position with the } \\
\text { help of the } \\
\text { instructor. } \\
\text { The instructor can } \\
\text { push the child into } \\
\text { the waves to help } \\
\text { the child catch the } \\
\text { wave with the } \\
\text { surfboard. } \\
\text { The child can } \\
\text { bodysurf the } \\
\text { waves without a } \\
\text { surfboard or use a } \\
\text { boogie board. }\end{array}$ \\
\hline $\begin{array}{l}\text { Moving into a standing } \\
\text { position- This was attempted } \\
\text { once the child progressed to } \\
\text { successfully catching waves in } \\
\text { the sitting or kneeling position. } \\
\text { (Please see figure } 8 \text { for a } \\
\text { photograph of the skill.) }\end{array}$ & $\begin{array}{l}\text { 1. Once you catch a wave } \\
\text { with your surfboard, pop } \\
\text { up to a standing position } \\
\text { on your surfboard. } \\
\text { 2. You can shift your } \\
\text { weight from right to left } \\
\text { to steer your surfboard } \\
\text { and ride the wave into the } \\
\text { beach. }\end{array}$ & 2. & $\begin{array}{l}\text { The instructor can } \\
\text { push the child into } \\
\text { the waves to help } \\
\text { the child catch the } \\
\text { wave with the } \\
\text { surfboard. } \\
\text { The child can } \\
\text { bodysurf the } \\
\text { waves without a } \\
\text { surfboard or use a } \\
\text { boogie board. } \\
\text { The instructor and } \\
\text { child can ride the } \\
\text { wave tandem in } \\
\text { the standing } \\
\text { position. } \\
\text { The child can use } \\
\text { a paddleboard }\end{array}$ \\
\hline
\end{tabular}




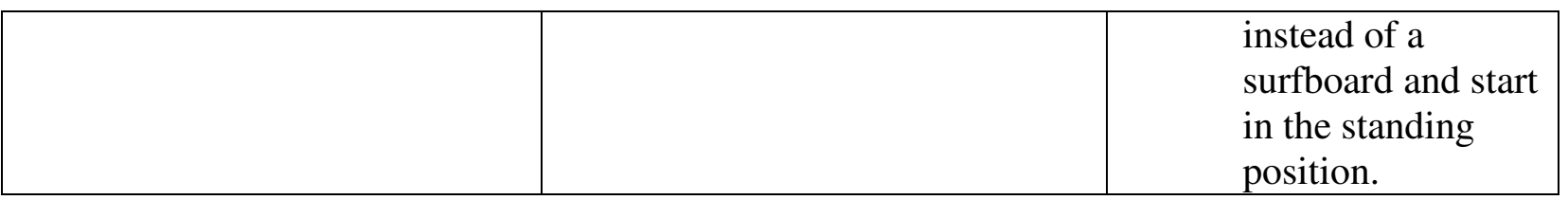

After each skill was practiced and mastered on the beach, the child and their instructor entered the water in pairs. They began in shallow water with each child given the opportunity to sit on the boards practicing balance in a stationary position as the surf instructor stabilized the

141 board as necessary. Once the child was able to perform a seated balance on the board, they 142 practiced lying on the board. Next they were encouraged to ride a wave into the beach while on 143 their stomachs and to progress to riding a wave while kneeling on the board. Once kneeling was 144 mastered, the child was encouraged to attempt standing up on the board and riding into the 145 beach. Each child progressed through these stages at their own individual pace over the course 146 of the program.

Throughout the program, the children and surf instructors were encouraged to set realistic individual goals. For instance, two children in the program were able to ride waves in the 149 standing position at the end of the program. Another was able to ride waves tandem with his surf instructor by hugging his instructor's waist. Yet another child was able to ride waves on her

151 stomach. Some children in the program solely focused on balancing and paddling their 152 surfboards with instructional help. Lastly, one child preferred to ride the waves with his body 153 instead of using a surfboard. All forms of surfing were encouraged and accepted by the program 154 leaders and surf instructors. Further, the program leaders, surf instructors and parents noted 155 dramatic physical and social improvements in all children regardless of the level of skill that was 156 finally achieved. Some of these improvements included increased verbalizations, excitement and 
157 enthusiasm about physical activity, motivation, improvements in surfing skills and love of the 158 ocean.

Overall there were many positive outcomes from this instructional surf program. The

161 following are some final thoughts from the program leaders: the children seemed more self-

162 confident, made gains in social development by interacting with volunteers and other

163 participants, appeared to be more relaxed in the water. The student volunteers participated in an 164 experiential learning environment outside of the classroom, which they will be able to apply to 165 their future professions. Most importantly, they learned strategies for working with a child with a 166 disability.

167 Furthermore, several outcomes of the program carried over into other areas of the 168 participants' lives. After the completion of the program, 8 of the 17 children went on to compete 169 in the Rhode Island Special Olympics State Games. They competed in several swimming and 170 track and field events. 3 of the 17 children participated in the Unified Sports through Special 171 Olympics and other inclusive sports offered at their schools. Participation in the surf program 172 could have given the participants the self-confidence, social skills and physical fitness necessary 173 for increased organized sport and physical activity participation. The program leaders are 174 currently searching for additional funding and plan on implementing the program again in the 
175 future $^{1}$.

176

${ }^{1}$ Grant funding to support the program was obtained from the University of Rhode Island's College of Human Science and Services $(\$ 5,000)$ and from the Fogarty Foundation $(\$ 4,000)$ and a local surf shop, Peter Pan Surf Academy, donated 50\% of the cost of the equipment rentals. 
THE OCEAN AS A UNIQUE THERAPEUTIC ENVIRONMENT

\section{References:}

Centers for Disease Control (2011). Signs \& Symptoms, Autism Spectrum Disorders. Retrieved from: http://www.cdc.gov/ncbddd/autism/signs.html.

Delaney, T \& Madigan, T. (2009). The Sociology of Sports: An Introduction. North Carolina: McFarland.

Diamond, K., \& Tu, H. (2008). Relations between classroom context, physical disability and preschool children's inclusion decisions. Journal of Applied Developmental Psychology, 7581. $\square$ Koury, J. (1996). Aquatic Therapy Programming. Champaign, IL: Human Kinetics.

Fragala-Pinkham, M., Haley, S.M., O’Neil, M.E, (2008). Group aquatic aerobic exercise for children with disabilities. Developmental Medicine \& Child Neurology. 50, 822-827.

Koury (1996). Aquatic Therapy Programming. Champaign, IL: Human Kinetics.

Matson, M.L., Matson, J.L., Beighley, J.S. (2011). Comorbidity of physical and motor problems in children with autism. Research in Developmental Disabilities. 32, 2304-2308.

Ming, X., Brimacombe, M., Wagner, G.C. (2007). Prevalence of motor impairment in autism spectrum disorders. Brain and Development. 29, 565-570.

Murphy, N.A. Carbone, P.S. \& Council on Children with Disabilities. (2008). Promoting the participation of children with disabilities in sports, recreation, and physical activities. PEDIATRICS, 121, 1057-1061.

Okagaki, L., Diamond, K. E., Kontos, S. J., \& Hestenes, L. L. (1998). Correlates of young children's interactions with classmates with disabilities. Early Childhood Research Quarterly, 67-86.

Rimmer, J. H., Riley, B., Wang, E., Rauworth, A., \& Jurkowski, J. (2004). Physical activity participation among persons with disabilities. American Journal of Preventative Medicine, 26-30.

Winnick, J.P. \& Short, F.X. (1999). The Brockport Physical Fitness Test Manual. Human Kinetics. 
203 World Health Organization. (2010) Global Recommendations of Physical Activity for Health.

204 Retrieved from whqlibdoc.who.int/publications/2010/9789241599979_eng.pdf

205 World Health Organization. (2012) Global Strategy on Diet, Physical Activity and Health:

206 Physical activity and young people. Retrieved from

207 http://www.who.int/dietphysicalactivity/factsheet_young_people/en/index.html

208 Yilmaz I, Yanardag M, Birkan B, Bumin G. (2004). Effects of swimming training on physical 209 fitness and water orientation in autism. Pediatrics International, 46, 624-626. 